\title{
Practice of traditional herbal medicine in animal husbandry of rural India
}

\author{
Deepandita Barman , Arunoday Das*, Maneesh Kumar Ahirwar**, Anup Kumar Singh*** and R. Vikram**** \\ Department of Livestock Production and Management, LCVSC, Assam Agricultural University, Joyhing-787051, Assam, India \\ *Department of ARGO, LCVSC, Assam Agricultural University, Joyhing-787051, Assam, India \\ **Veterinary Hospital, Ratlam-457001, Madhya Pradesh, India \\ ***Department of Livestock Production and Management, IIVER, Rohtak-124022, Haryana, India \\ ****Animal Reproduction, ICAR-NRC on Mithun, Medziphema-797106, Nagaland
}

\section{Article Info}

Article history

Received 7 October 2021

Revised 25 November 2021

Accepted 27 November 2021

Published Online 30 December 2021

\section{Keywords}

Health

Harbal medicine

Livestock

Management

\begin{abstract}
Traditional knowledge of herbal medicines has a rich heritage in Indian culture which stands as a unique wisdom to common society, scientists and planners that are involved in development projects. In India, farmer practices much indigenous technical knowledge in different field of livestock management to improve digestibility, milk production and wound treatment. Various extracts from plants are prepared as herbal medicine, have been used since decades for disease management such as general debilitation, indigestion and lack of appetite which are yet be further analyzed scientifically in livestock sector. $41 \%$ leaves and $21 \%$ seeds followed by $10 \%$ fruits from plant parts are used for the treatment of veterinary ailments. Today, practices of many traditional herbal medicines are disappearing only because of the intrusion of foreign technologies or development of new concepts towards modern veterinary drugs. Traditional knowledge is always acceptable in rural communities as it incur low expense preparation, local availability and easy administration which are sustainable to social and cultural habitats. Therefore, the collection of knowledge is of great significance to sustain the productivity, protecting the ecosystem and help to develop alternatives to ecologically damaging the animal husbandry practices.
\end{abstract}

\section{Introduction}

India is a country of rich heritage practices of indigenous health control and treatment systems that have been used for animals since long generations. Indigenous technical knowledge (ITK), referred to as traditional knowledge/wisdom. It is evolved by members of the farm community and passed on from, generation to generation, or developed on the basis of recent experiment by farmers. ITK is unique to a given culture and society, but it has value also for the scientists and planners that are involved in development projects.

The knowledge of indigenous practices drains from one down to the next generation by as comprehensive approach for livestock management approach for poor farmers. At present, the ITKs and its systems are at great risk due to rapid environmental change and pacing of social, economic, political and cultural changes on a global scale. The word 'indigenous' depicts "native born, which means natural origin or produce in a country or in any specified area" and the word 'knowledge' means "assured belief, practical skill, that which is known, learning and enlightenment" (Reijntjes et al., 1992).

In India, the ITK's are basically more popularize among the local people including farmers, rural artisans, landless labours, rural women, animal husbandry practitioners, etc., which earn their

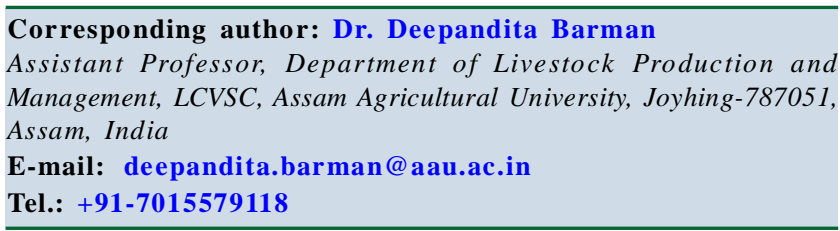

Copyright () 2021 Ukaaz Publications. All rights reserved.

Email: ukaaz@yahoo.com; Website: www.ukaazpublications.com livelihood through their own capacity of having little systematic knowledge as well as knowing the mechanism of how indigenous practices work for various ailments of animal husbandry. The indigenous technical knowledge system also helps the practitioners to cope with problematic situations through surviving in tremendous odds. Today, such practices are diminishing rapidly with the deceased farmer, bearing scientific and traditional knowledge because such people who serve the community are afraid to tell others about the usefulness of the herbal drugs looking to their gradual exploitation. Hence, it is necessary to identify the perceived effectiveness of such indigenous practices for their further scientific validation in various national and international research organizations (Singh and Chauhan, 2010). It is extremely difficult to acquire indigenous knowledge which is regarded as secrete or confidential. Moreover, since indigenous knowledge is not documented but stored in peoples' minds, it bears a high risk of losing it. Maundu (1995) stated that indigenous knowledge is diminishing at an alarming rate with the ageing of those in the indigenous population with strong links to the past. Majority of Indians depend on agricultural system which further can enhance the quality of their life with the practice of rich Indian tradition of ITK (Berkes and Folke, 1994).

Innovation is the first attempt to carry out an invention in practice. Fagerberg (2006) said that the knowledge which inherently possess by the indigenous communities is used for purposes of ranging from natural resource management, agriculture, medicine to other socioeconomic developments, and thus it instigates the process of innovation. The innovative minds of local farmers disseminate the traditional knowledge for a society which facilitates them to further communicate and decision-making in that geographical area for 
efficacy of the herbal medicines (Shubeena et al., 2018). The rural people possess much traditional and deeper knowledge of their surroundings and adopt them based on needs to solve local problems in managing agricultural and related activities (Nabukenya et al., 2014). It has been observed that the traditional knowledge of herbs among villagers help them to diagnose the particular disorder and disease in agricultural crops, vegetables, as well as in livestock and its management are practiced usually through their own capabilities as proved and disseminated by their ancestors (Ranjanna et al., 2013). This technique is based on the assumption criteria, reliable evidences, economic viability, farming community consent, traditional sound knowledge, and positive result of farmers after being used once. Villagers in hilly areas are more thoughtful to adopt and practice ITK's as they are distant away from developments (Santosh and Chhetry, 2012). They easily follow the traditional knowledge that they have learnt from their older generations (Singh and Tyagi, 2014).

\section{Plants used in different field of livestock management}

\subsection{Herbs to increase digestibility and milk production}

Glyricidia (G. maculata) and roasted soaked tamarind seeds is considered to increase lactation in cows (Ponnusamy et al., 2009). Also, to improve lactation in animals, $4 \mathrm{~kg}$ each of soaked cottonseed, bengal gram and horse gram are soaked, ground can be fed. It has also been reported the seeds of subabul (Leucaena leucocephala) which also fed to animals to improve the milk secretion. Bottle gourd (Lagenaria siceraria) with fenugreek (Trigonella foenum-graceum), coconut, black gram (Vigna mungo) and palm jiggery mixed with water is given for 3 days to improve the milk yield. Dried flowers of Madhuca latifolia (Illupsi) are given to improve the working efficiency of the bullock. Prospisjulifera fruits with jiggery and rice flour are given to improve digestibility. Asafoetida (Ferula asafetida) ground with gur is given to animals as ball to improve digestibility. Pepper, jaggery and betel leaf (Piper betle) powder is given to animals to increase digestibility.

In Kashmir, grinded mazamund (Iris kashmiriana) and jiggery are used in bolus form and given to animals to increase the milk productivity and also to overcome general debility body condition (Shubeena et al., 2018). Among many plants, soyabean, cowpea and wheat are considered to be commonly used by farmers for milk production purpose and to enhance the body condition after parturition.

\subsection{Herbs to enhance general health management}

There is a common belief in farmers of Bihar that buring of tortoise shell near animal shed protects animals from foot and mouth disease (Mishra et al., 2011). Farmers believe that cows with triangular shape, small legs, broad hind part, narrow fore part, and soft and shiny skin are considered as high milk producing cow (Chander et al., 2011).

For general debilitation, indigestion and lack of appetite, extracts of omum (Trachyspermum ammi), black cumin (Nigella sativa), pepper (Piper nigrum), gingelly (Sesamum indicum) and cardamom (Elettaria cardamomum) are given to cure digestibility problems. To activate the enzymatic activity and to induce the appetite, usually betel leaf and pepper ground are mixed with coconut oil fed to animals. Also, Agave sisalna is peeled and kept in the roof during night and given to animals in the morning. Thorn apple (Datura stramonium) seeds ( $3 \mathrm{gm})$, areca nut (20 gm) and white clay (500 gm) mixed with rice gruel is given twice a day to treat diarrhea (Ponnusamy et al., 2009). It has also been found that the neem (Margosa tree, Azadirachta indica) leaves and bark of daka and bark of Daniaa are mixed and sap is extracted from the mixture and then $100 \mathrm{ml}$ of it is drenched everyday to increase digestibility for 3-4 days (De et al., 2004). Drenching about $1 \mathrm{~kg}$ fruit pulp extract of Aegle marmelos and mango seed kernal for 2-3 days are also found helpful to treat diarrhea (Balakrishnan et al., 2009).

To prevent intestinal worms, powder of subabul seeds mixed with water is given to goats. Leaves, flowers and bark of neem along with $100 \mathrm{gm}$ of cucumber (Cucumis sativus) seeds are given for 3 days. It has been found that to treat milk fever leaves of indigo (Indigo feratinctoria) made as tablets are given to animals. Similarly, to reduce cold and cough, it is believed that equal amount of holy basil (Tulsi leaves, Ocimum sanctum) and basak leaves (Adhatoda vasica) boiled with water can be fed to the animals especially in winter season. Then extracted juice is mixed with 1-teaspoon honey and fed to the animal (De et al., 2004).

To cure the wounds, juice of sacred basil mixed with camphor is applied on the wounds. Leaf juice of thumbai (Leucus lavandulaefolia) is applied on the wounds (Ponnysamy et al., 2009). haldi (Turmeric, Curcuma domestica) has lots of antimicrobial and herbal property which is grounded in powder form and can be applied topically in wound to prevent entry of microorganisms and also prevent the formation of maggots. Extract of ganda (African marigold, Targetes erecta) leaves is applied topically. Jiyeti plant (Sesbania sesban) is known for its traditional medicinal property and can be used by burning for making the ash of jiyeti is mixed with coconut oil and applied topically to reduce the inflammatory reaction. Often, the inflammatory condition get worsen up, if the wound infested with worms and turned out be maggoted wound. In this condition, the seeds of ata (Custard apple, Annona squamosa) can be useful in powdered form for topical application for the treatment of worm-infested wound (De et al., 2004).

Farmers commonly use paste made from famously known healing tree of bael (Aegle marmelos) leaves use for 4-5 days to reduce shoulder pain of working ox as the plant has anti-inflammatory property (Mishra et al., 2011). For poisonous bites, juice of sacred basil and Acalypha indica is poured in the nostrils. Paste of Aristolochia gigas (pelican flower) mixed with equal quantity of butter is given to the animal (Ponnysamy et al., 2009). The paste made from the roots of bonson tree mixed with 21 pieces, golmorich (Black pepper, Piper nigrum) fed to animals for treating all the dog bites injury. Jaggery, garlic and ginger paste is given to the animals and is found beneficial to prevent bloat (De et al. 2004). Tympany can be treated by drenching linseed oil along with a mixture of ginger, turmeric and asafetida by keeping the animal's mouth open via tying a piece of wood into it (Balakrishnan et al.,2009). Applying turmeric on udder is found as herbal treatment of mastitis.

The common farmers of Bihar used to chant mantra to prevent animals from Khurha (FMD) by applying red ink drop on tender bamboo leaves especially on Saturday and believed mantra is "Aage 
Arjun Pichhe Bhim, Khurha Mare Champaseen! Chhoote Laar Na Phate Khari Duhai Shrikrishna Chandra k". Howevere, a mixed dose of $200 \mathrm{~g}$ of ginger (Zingiber officinale), turmeric (Curcuma longa) and garlic (Allium sativum) each in month of May, keeps foot and mouth disease away (Mishra et al., 2011). Allowing animals to walk in hot sand and applying sand to wounds externally; applying linseed oil and turmeric externally; applying kerosene, if the wounds are infested with maggots (Balakrishnan et al., 2009).

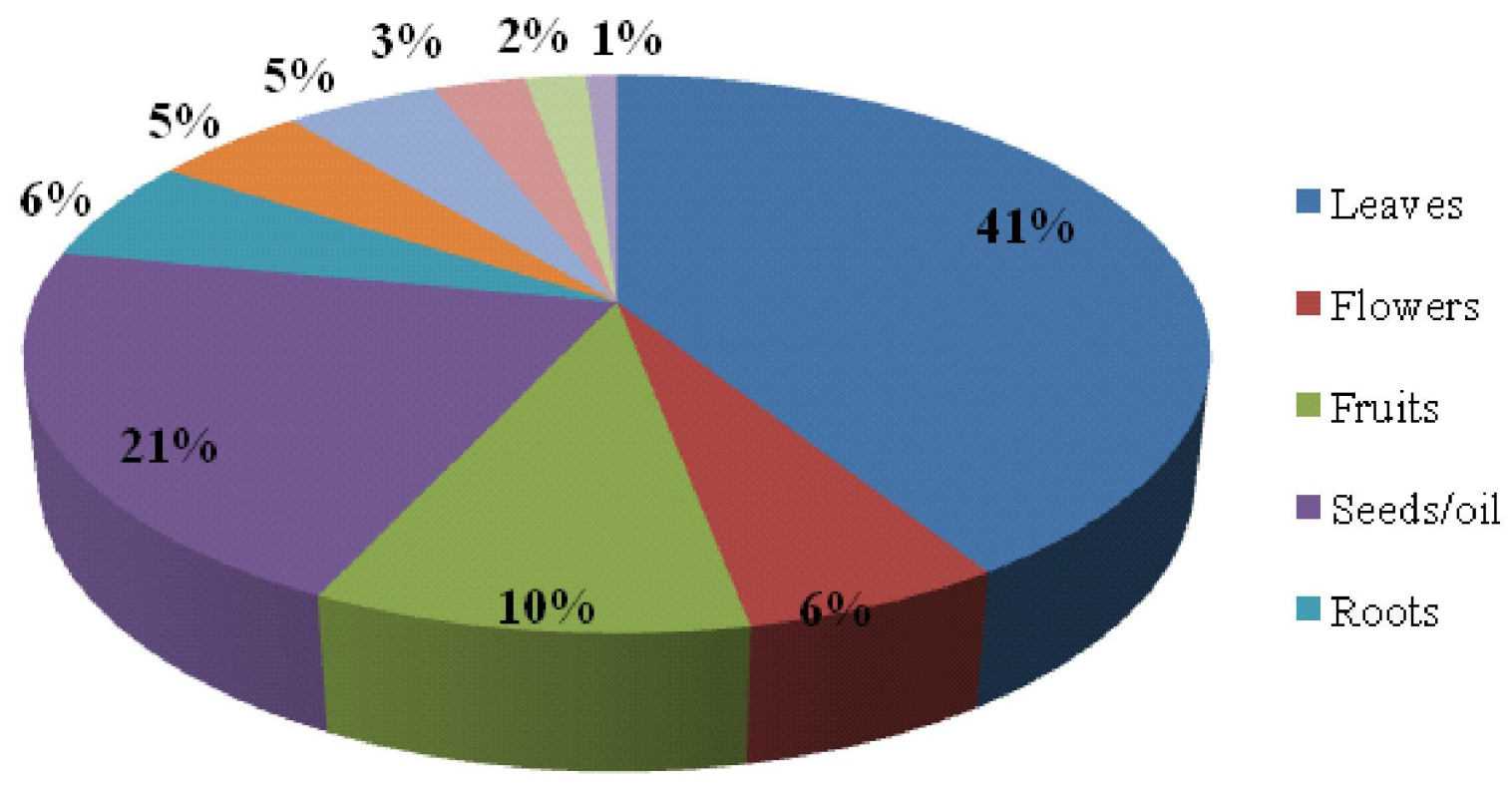

Figure 1: Percentage of plant parts used for the treatment of veterinary ailments.

(Sehgal, A.B. and Sood, S.K., 2013)

Table 1: List of the plants, usage and their active ingredients

\begin{tabular}{|c|c|c|c|c|c|c|}
\hline Sr. No. & Common name & Scientific name & Active ingredients & Usage & References & Pictures \\
\hline 1. & Ajwain & Trachyspermum ammi & Thymol and carvacrol & $\begin{array}{l}\text { Antiseptic, } \\
\text { antitussive } \\
\text { and } \\
\text { expectorant } \\
\text { properties }\end{array}$ & $\begin{array}{l}\text { Trease and } \\
\text { Evans, } 2002\end{array}$ & 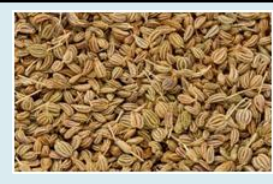 \\
\hline 2. & Black cumin & Nigella sativa & Thymoquinone (TQ) & $\begin{array}{l}\text { Production } \\
\text { of cytokine } \\
\text { interferon- } \\
\text { gamma } \\
\text { against } \\
\text { infection }\end{array}$ & $\begin{array}{l}\text { Salem et al., } \\
2011\end{array}$ & \\
\hline 3. & Pepper & Piper nigrum & Piperine & $\begin{array}{l}\text { Natural } \\
\text { bioenhancer } \\
\text { potentiate } \\
\text { the } \\
\text { therapeutic } \\
\text { effect }\end{array}$ & $\begin{array}{l}\text { Corinna et al., } \\
2012\end{array}$ & \\
\hline 4. & Sesame (Gingelly) & Sesamum indicum & $\begin{array}{l}\text { Lignan, phenolic acid, } \\
\text { flavonoids, saponin and } \\
\text { alkaloids }\end{array}$ & $\begin{array}{l}\text { Potential } \\
\text { source of } \\
\text { micro- } \\
\text { nutrients }\end{array}$ & $\begin{array}{l}\text { Hassan and } \\
\text { Umar, } 2004\end{array}$ & \\
\hline 5 . & Cardamom & Elettaria cardamomum & 1,8 -cineole & $\begin{array}{l}\text { Potent } \\
\text { expectorant } \\
\text { and } \\
\text { antiseptic }\end{array}$ & $\begin{array}{l}\text { Sengupta and } \\
\text { Bhattacharjee, } \\
2009\end{array}$ & \\
\hline
\end{tabular}




\begin{tabular}{|c|c|c|c|c|c|c|}
\hline 6. & Sisal hemp & Agave sisalna & $\begin{array}{l}\text { Sterols, steroidal } \\
\text { sapogenins and } \\
\text { steroidal alkaloids }\end{array}$ & $\begin{array}{l}\text { Antheminitic } \\
\text { and immun- } \\
\text { omodulatory } \\
\text { activity }\end{array}$ & $\begin{array}{l}\text { Tewari et al., } \\
2014\end{array}$ & ant \\
\hline 7. & Thorn apple seeds & Datura stramonium & $\begin{array}{l}\text { Hyoscyamine and } \\
\text { scopolamine }\end{array}$ & $\begin{array}{l}\text { Antiasthmatic, } \\
\text { anticholinergic } \\
\text { and } \\
\text { antimicrobial } \\
\text { activity }\end{array}$ & $\begin{array}{l}\text { Li } \text { et al., } \\
2012\end{array}$ & \\
\hline 8. & Areca nut & Areca catechu & $\begin{array}{l}\text { Arecoline, } \\
\text { arecaidine, } \\
\text { guvacine, and } \\
\text { guvacoline }\end{array}$ & $\begin{array}{l}\text { Antibacterial, } \\
\text { antiviral and } \\
\text { antitumor and } \\
\text { anthelmintic } \\
\text { action }\end{array}$ & $\begin{array}{l}\text { Xiao et al., } \\
2019\end{array}$ & \\
\hline 9. & Neem & Azadirachta indica & Azadirachtin & $\begin{array}{l}\text { Antioxidant } \\
\text { and } \\
\text { anticancerous } \\
\text { activity }\end{array}$ & $\begin{array}{l}\text { Alzohairy, } \\
2016\end{array}$ & \\
\hline 10 & Stone apple & Aegle marmelos & Aeglemarmelosine & $\begin{array}{l}\text { Antidiarrheal } \\
\text { and } \\
\text { antidysentery } \\
\text { property }\end{array}$ & $\begin{array}{l}\text { Laphookhieo } \\
\text { et al., } 2011\end{array}$ & \\
\hline 11. & Cucumber & Cucumis sativus & $\begin{array}{l}\alpha \text {-linolenic acid, } \\
\text { Caffeic acid, } \\
\text { Citrulline and } \\
\text { Cucurbitin B }\end{array}$ & $\begin{array}{l}\text { Antioxidant and } \\
\text { analgesic effect }\end{array}$ & $\begin{array}{l}\text { Shah et al., } \\
2013\end{array}$ & \\
\hline 12. & Indigo & Indigofera tinctoria & Galactomannan & $\begin{array}{l}\text { Antihyper- } \\
\text { glycemic and } \\
\text { antibacterial } \\
\text { activity }\end{array}$ & $\begin{array}{l}\text { Motamarri } \\
\text { et al., } 2012\end{array}$ & 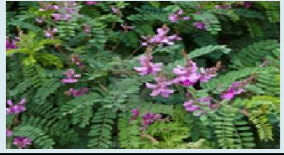 \\
\hline 13. & Tulsi & Ocimum sanctum & $\begin{array}{l}\text { Oleanolic acid, } \\
\text { Ursolic acid and } \\
\text { Rosmarinic acid }\end{array}$ & $\begin{array}{l}\text { Inflammation } \\
\text { and wound } \\
\text { healing }\end{array}$ & $\begin{array}{l}\text { Panchal and } \\
\text { Parvez, } 2019\end{array}$ & 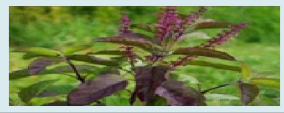 \\
\hline 14. & Basaka & Adhatoda vasica & $\begin{array}{l}\text { Pyrroloquinazoline } \\
\text { alkaloids }\end{array}$ & $\begin{array}{l}\text { Expectorant, } \\
\text { abortifacient, } \\
\text { antimicrobial, } \\
\text { antitussive and } \\
\text { anticancer }\end{array}$ & $\begin{array}{l}\text { Soni et al., } \\
2008\end{array}$ & \\
\hline 15. & Thumbai & Leucus lavandulaefolia & $\begin{array}{l}\text { Acacetin, } \\
\text { chrysoeriol, } \\
\text { linifoliside, } \\
\text { triterpenoids and } \\
\text { steroids }\end{array}$ & $\begin{array}{l}\text { Laxative, } \\
\text { anthelmintic, } \\
\text { antijaundice } \\
\text { property }\end{array}$ & $\begin{array}{l}\text { Begum } \\
\text { et al.,2015 }\end{array}$ & 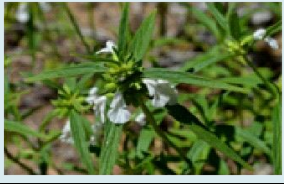 \\
\hline 16. & Turmeric & Curcuma domestica & $\begin{array}{l}\text { Nonvolatile cur- } \\
\text { cuminoids and the } \\
\text { volatile oil }\end{array}$ & $\begin{array}{l}\text { Anti-inflamma- } \\
\text { tory, } \\
\text { anticancerous, } \\
\text { hypocholes- } \\
\text { terolemic, anti- } \\
\text { proliferative, } \\
\text { and many other } \\
\text { properties }\end{array}$ & $\begin{array}{l}\text { Dosoky and } \\
\text { Setzer, } 2018\end{array}$ & \\
\hline 17. & African marigold & Tagetes erecta & $\begin{array}{l}\text { Syringic acid, } \\
\text { quercetin and } \\
\text { 6-hydroxykaemp- } \\
\text { ferol }\end{array}$ & $\begin{array}{l}\text { Central nervous } \\
\text { system stimul- } \\
\text { ant, antioxidant, } \\
\text { antidepressant, } \\
\text { and antipyretic } \\
\text { in nature }\end{array}$ & $\begin{array}{l}\text { Vedam et al., } \\
2019\end{array}$ & 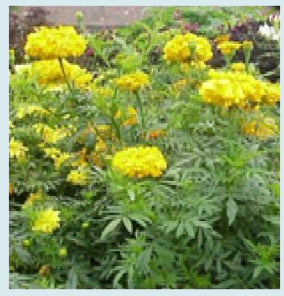 \\
\hline
\end{tabular}




\begin{tabular}{|c|c|c|c|c|c|c|}
\hline 18. & Egyptian pea & Sesbania sesban & Anthocyanin & $\begin{array}{l}\text { Antimicrobial, } \\
\text { molluscicide, } \\
\text { anti-inflamma- } \\
\text { tory, CNS- } \\
\text { stimulant and } \\
\text { nephroprotec- } \\
\text { tive properties }\end{array}$ & $\begin{array}{l}\text { Walekhwa } \\
\text { et al., } 2020\end{array}$ & 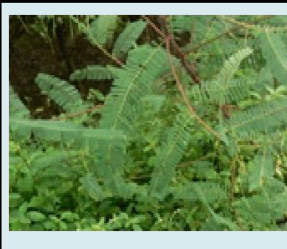 \\
\hline 19. & Custard apple & Annona squamosa & Squamocin & $\begin{array}{l}\text { Cytotoxic, } \\
\text { antimicrobial, } \\
\text { antioxidant, } \\
\text { antitumor and } \\
\text { insecticidal } \\
\text { properties }\end{array}$ & $\begin{array}{l}\text { Mondal et al., } \\
2018\end{array}$ & \\
\hline 20. & Indian copperleaf & Acalypha indica & $\begin{array}{l}\text { Ellagic acid, gallic } \\
\text { acid and kauren- } \\
18 \text {-oic-acid }\end{array}$ & $\begin{array}{l}\text { Antibacterial, } \\
\text { anticancer, } \\
\text { antidiabetic, } \\
\text { antioxidant, }\end{array}$ & $\begin{array}{l}\text { Chekuri et al., } \\
2020\end{array}$ & $E^{2}+25$ \\
\hline 21. & Pelican flower & Aristolochia gigas & Aristolochic acids & $\begin{array}{l}\text { Insecticidal and } \\
\text { repellent } \\
\text { activities }\end{array}$ & $\begin{array}{l}\text { Kuo et al., } \\
2012\end{array}$ & \\
\hline 22. & Garlic & Allium sativum & $\begin{array}{l}\text { Ajoenes, thiosul- } \\
\text { finates and } \\
\text { vinyldithiins }\end{array}$ & $\begin{array}{l}\text { Antibacterial, } \\
\text { antifungal, } \\
\text { antiprotozoal, } \\
\text { antiviral, } \\
\text { antioxidant } \\
\text { and anti- } \\
\text { inflammatory } \\
\text { properties }\end{array}$ & $\begin{array}{l}\text { Batiha et al., } \\
2020\end{array}$ & $8{ }^{6}$ \\
\hline 23. & Ginger & Zingiber officinale & $\begin{array}{l}\text { Gingerols, shogaols, } \\
\text { and paradols. }\end{array}$ & $\begin{array}{c}\text { Antioxidant and } \\
\text { anti-inflamma- } \\
\text { tory activity }\end{array}$ & $\begin{array}{l}\text { Mao et al., } \\
2019\end{array}$ & 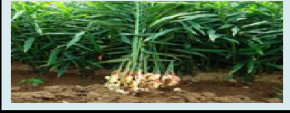 \\
\hline 24. & Eucalyptus & Glyricidia maculate & $\begin{array}{l}\text { Monoterpenes and } \\
\text { sesquiterpenes }\end{array}$ & $\begin{array}{l}\text { Antimicrobial } \\
\text { and antioxidant } \\
\text { property }\end{array}$ & $\begin{array}{l}\text { Almas et al., } \\
2021\end{array}$ & \\
\hline 25. & Subabul & Leucaena leucocephala & $\begin{array}{l}\text { Caffeic acid, } \\
\text { Isorhamnetin and } \\
\text { Chrysoeriol }\end{array}$ & $\begin{array}{l}\text { Antioxidant and } \\
\text { cytotoxic } \\
\text { activity }\end{array}$ & $\begin{array}{l}\text { Hassan et al., } \\
2013\end{array}$ & 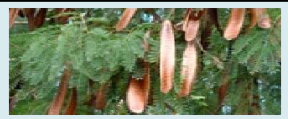 \\
\hline 26. & Fenugreek & $\begin{array}{l}\text { Trigonella } \\
\text { foenum-graceum }\end{array}$ & $\begin{array}{l}\text { Alkaloids, } \\
\text { carbohydrates, } \\
\text { steroidal saponins, } \\
\text { amino acids and } \\
\text { minerals }\end{array}$ & $\begin{array}{l}\text { Elevates pro- } \\
\text { inflammatory } \\
\text { cytokines and } \\
\text { a potent } \\
\text { anticancer } \\
\text { activity }\end{array}$ & $\begin{array}{l}\text { Syed et al., } \\
2020\end{array}$ & 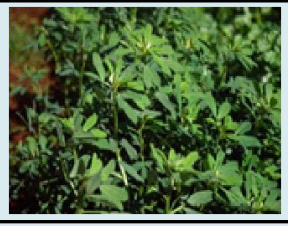 \\
\hline 27. & Asafoetida & Ferula asafetida & $\begin{array}{l}\text { Ferulic acid and } \\
\text { asaresinotannols }\end{array}$ & $\begin{array}{l}\text { Antispasmodic, } \\
\text { analgesic, } \\
\text { diuretic and } \\
\text { vermifugal } \\
\text { action }\end{array}$ & $\begin{array}{l}\text { Mahendra and } \\
\text { Bisht, } 2012\end{array}$ & \\
\hline 28. & Mazamund & Iris kashmiriana & $\begin{array}{l}\text { Flavonoid, phenol } \\
\text { and gallic acid }\end{array}$ & $\begin{array}{l}\text { Potent } \\
\text { antibacterial } \\
\text { properties }\end{array}$ & $\begin{array}{l}\text { Shubeena } \\
\text { et al., } 2018\end{array}$ & \\
\hline 29. & Illupsi & Madhuca latifolia & $\begin{array}{l}\text { Quercetin, } \\
\text { taxifoline and } \\
\mathrm{t} \text { glucosides }\end{array}$ & $\begin{array}{l}\text { Skin diseases, } \\
\text { rheumatism } \\
\text { and headaches }\end{array}$ & $\begin{array}{l}\text { Khana et al., } \\
2011\end{array}$ & \\
\hline 30. & Bottle gourd & Lagenaria siceraria & $\begin{array}{l}\text { Triterpene } \\
\text { bryonolic } \\
\text { acid }\end{array}$ & $\begin{array}{l}\text { Antiallergic } \\
\text { properties }\end{array}$ & $\begin{array}{l}\text { Shah et al., } \\
2010\end{array}$ & 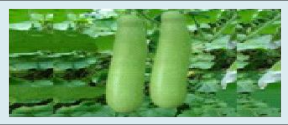 \\
\hline
\end{tabular}




\section{Ethnoveterinary preparations}

The folk health practices largely remain undocumented and are passed on from one generation to the other by word. The efforts are aim to encourage the use of ethnoveterinary knowledge throughout the world, so as to document more traditional knowledge and information in the field reports and scientific publications. The most common forms of ethnoveterinary preparations are powders, poultice, ointment, decoction, infusion, coldware extract, tincture and fumigation (Sri Balaji and Chakravarthi, 2010).

\section{Problems/disadvantages}

Each technology or concept has limitations, and ITK is no exception, e.g., the scope for improvements based on ITK are limited to what can be done with local techniques, materials and genetic resources. Many new developmental techniques including information related to genes, techniques, materials, etc. may, be unknown and cannot be possible sometimes to explore with the informal system.

The informal system does not have required upgraded perspective and information to anticipate the valid opportunities and constraints that arise from the changing environments. Also, the indigenous and traditional materials which include herbs and methods of using it vary from one region to another, as the traditional use of indigenous knowledge is unique to a particular culture (Rao et al., 1995).

\section{Advantages}

The poor farmers perceive the traditional knowledge as more favourably accepted among all the rural communities due to its cost effectiveness, local availability in village flora and fauna, easy in preparation and administration, compatible to social and cultural habitats which make its overall sustainability. The available ITK are based on the trials performed by their ancestors since generations and found effective in rural settings where veterinary facilities are not available in emergency case (Singh, and Chauhan, 2010). Indigenous knowledge is often the most suitable, economic and economically friendly and has no adverse effect (Rahman, 2012).

These Indigenous Practices may be recommended and disseminated among the farmers where MVD (Modern Veterinary Drug) is not easily accessible. Further, the practices can also be blended with MVD through laboratory research, tests and scientific rationality (De et al., 2004).

\section{Risk assessment of traditional knowledge}

Today, many indigenous knowledge systems are at risk of becoming extinct because of rapidly changing natural environment, fast pacing economic, political cultural changes on a global scale and practices vanish and diminishing as they become inappropriate and inefficient for new challenges due to which they adapt too slowly.

However, many practices have been disappeared only because of the intrusion and use of foreign and modern technologies with the upgraded development concepts which promise the gains and solutions of many problems within the short period of time without being capable of sustaining them. This over estimation of modern practices does not last long because of the side effects that triggered by the increased use of chemicals in various areas of life. This lead to a reconsideration of traditional systems of treatments, and thus a increased demand of natural products in form of drugs, foods, cosmetics, etc., has been noticed in recent years. These skills are transmitted to younger girls and, in some cases, boys, through socialization and apprenticeship (Mukherjee, 2002; Bodeker et al., 2005; Bandaranayake, 2006).

\subsection{Risk management}

The importance of documenting ancient/indigenous/traditional knowledge has recently gained a momentum allover the world including India. In India, several non-government organizations:

(a) BAIF, Pune;

(b) JagaranVikas Kendra, Udaipur;

(c) ANTHRA, Pune;

(d) SALIHOTRA, M.P.;

(e) Appropriate Technology of India, Ahemdabad;

(f) Women's Organization for Rural Development (WORD), Ahemdabad and

(g) Grassroots Innovation Augmentation Network (GIAN), Gujarat is reported to be involved in documentation and validation of indigenous technical knowledge system.

\section{Conclusion}

Today, practices of many traditional herbal medicines are disappearing only because of the introduction of many modern technologies and development of new concepts towards modern veterinary drugs, which leads to diminishing the usage of traditional knowledge among farmers community. The advantages of these wisdoms which passed from generation to generation has helped the farmers in many different ways such as cost effectiveness, ready availability in flora and fauna, easy administration mode, etc. Therefore, this collection of knowledge is of great significance to sustain the productivity, protecting the ecosystem and help to develop alternatives to ecologically damaging the animal husbandry practices which will lead to sustainability in the long run. If, ITKs were used in farming systems along with frontier technologies developed by the agricultural scientists, it would be more practical and not only the farmers would adopt quickly but also increase the beneficiary, practicability and acceptability of technology for betterment of mankind. Government and non-government organizations must work in relation to preservation of indigenous species of plants and development of herbal medicines.

\section{Acknowledgments}

We would like to thanks Associate Dean and Management of Lakhimpur College of Veterinary Science, Assam Agricultural University for their support and encouragement.

\section{Conflict of interest}

The authors declare no conflicts of interest relevant to this article.

\section{References}

Almas, I.; Innocent, E.; Machumi,F. and Kisinza, W. (2021). Chemical composition of essential oils from Eucalyptus globulus and Eucalyptus maculata grown in Tanzania. Scientific African, 12: e00758. https:// doi.org/10. 1016/j. sciaf.2021. e00758. 
Alzohairy, M.A. (2016). Therapeutics role of Azadirachta indica (Neem) and their active constituents in diseases prevention and treatment. Evid Based Complement Alternat Med. https:// doi: $10.1155 / 2016 / 7382506$

Balakrishnan, V.; Philip R. J.; Manickasamy A. and Ravindran, K.C. (2009). Ethnoveterinary studies among farmers in Dindigul district Tamil Nadu, India. Global Journal of Pharmacology, 3(1):15-23.

Bandaranayake, W. M. (2006). Quality control, screening, toxicity, and regulation of herbal drugs. Modern Phytomedicine Turning Medicinal Plants into Drugs, pp:25-57.

Batiha, G. E.; Beshbishy A. M.; Wasef, L.G. and Elewa, Y. H. A. (2020). Chemical constituents and pharmacological activities of Garlic (Allium sativum L.): A review. Nutrients, 12(3):872.

Begum, P; Wang, Y. and Fugetsul, B. (2015). Biologically active compounds from Leucas lavandulaefolia. International Journal of Pharmaceutical Sciences and Research. 6(3):1013-1021.

Berkes, F. and Folke, C. (1994). Linging social and ecological systems for resilience and sustainability. Stockholms: The Badger Internationa Institute of Ecological Economics, the Royal Swedish Academy of Science.

Bodeker C.; Bodeker G.; Ong C. K.; Grundy C. K.; Burford G. and Shein, K. (2005). WHO Global Atlas of Traditional, Complementary and Alternative Medicine. Geneva, Switzerland: World Health Organization.

Chander, M.; Subrahmanyeswari,B.; Mukherjee, R. and Kumar, S. (2011). Organic livestock production: an emerging opportunity with new challenges for producers in tropical countries. Revue scientifique technique OIE, 30(3):969-98.

Chandra, S.; Chakrabarty, A.; Biswas, S.; Guha, C. and Sarkar, S. (2012). Validation of selected ethno-veterinary practices through farmer participatory research approach in Jalpaiguri district of West Bengal. International Journal of Bioresource and Stress Management, 3(4):449-454.

Chekuri, S.; Lingfa, L; Panjala, S.; Sai Bindu, K. C. and Anupalli, R. R. (2020) Acalypha indica L.: An important medicinal plant: A brief review of its pharmacological properties and restorative potential. European Journal of Medicinal Plants, 31(11):1-10.

Corinna, D.; Henze, A.; Frank, O.; Glabasnia, A.; Mathias, R.; Buning, K; Orlikowski, D.; Bader, M. and Hofmann, T. (2012). Structural and sensory characterization of key pungent and tingling compounds from black pepper (Piper nigrum L.). Journal of Agricultural Food Chemistry, 60(11):2884-2895.

De, A.; Arya, H. P.S.; Babulal, T. and Goswami, A. (2004). Indigenous technical knowledge in animal husbandry. Livestock Research for Rural Development, 16:8.

Dosoky N. S. and Setzer W. N. (2018). Chemical composition and biological activities of essential oils of Curcuma Species. Nutrients. 10(9): 1196

Fagerberg, J.; Mowery, D.C. and Nelson, R. R. (2006). The Oxford Handbook of Innovation, (Oxford University Press).

Hassan, R. A. ; Tawfik, W. A. and Abou-Setta, L. M. (2013). The flavonoid constituents of Leucaena leucocephala. growing in Egypt, and their biological activity. African Journal of Traditional, Complementary and Alternative Medicines, 11(1):67-72.

Hassan, L. G. and Umar, K. J. (2004). Proximate and mineral composition of seeds and pulp of Parkla biglobasa L. Nigeria Journal of Basic and Applied Sciences, 13:15-27.
Khana, S.; Nadeem, K. M. and Siddiqui, B.S. (2011). Arbutin derivatives from the seeds of Madhuca latifolia. Natural Product Communications, 6 (11):1661-1664.

Kuo, P. C.; Li, Y. C. and Wu, T. S. (2012). Chemical constituents and pharmacology of the Aristolochia (madou ling) species. Journal of Traditional and Complementary Medicine, 2(4):249-266.

Laphookhieo, S.; Phungpanya, C.; Tantapakul, C.; Techa, S.; Tha-in, S. and Narmdorkmai, W. (2011). Chemical constituents from Aegle marmelos. Journal of Brazilian Chemical Society, 22(1):176-178.

Li, J.; Lin, B; Wang, G; Gao, H. and Qin, M. (2012). Chemical constituents of Datura stramonium seeds. Zhongguo. Zhong. Yao. Za. Zhi., 37(3):319-322.

Mahendra, P. and Bisht, S. (2012). Ferula asafetida: Traditional uses and pharmacological activity. Pharmacognosy Reviews, 6(12):141-146.

Mao, Q.Q; Yu Xu, X.; Cao, S.Y.; Gan, R. U; Harold Corke, Beta, T. and Li, H.B. (2019). Bioactive compounds and bioactivities of ginger (Zingiber officinale) Roscoe. Foods, 8(6):185.

Maundu, P. (1995). Methodology for collecting and sharing indigenous knowledge: A case study. Indigenous Knowledge and Development Monitor, 3(2):25-27.

Mishra,O.P.; Singh, A.K. and Kumar, S. (2011). Indigenous knowledge of Bihar farmers. Journal of Community Mobilization and Sustainable Development, 6(1):046-049.

Mondal, P.; Biswas, S.; Pal, K. and Ray, D. P. (2018). Annona squamosa as a potential botanical insecticide for agricultural domains: A review. International Journal of Bioresource Science, 5(1):81-89.

Motamarri, N.S.; Karthikeyan, M.; Rajasekar, S. and Gopal, V. (2012). Indigofera tinctoria Linn. International Journal of Research in Pharmaceutical and Biomedical Sciences, 3(1):164-169.

Mukherjee, P. W. (2002). Quality Control of Herbal Drugs: An approach to evaluation of botanicals. New Delhi, India: Business Horizons Publishers.

Nabukenya, I.; Chris, R. A.; Olila, D.; Ikwap, K. and Hoglund, J. (2014) Ethnopharmacological practices by livestock farmers in Uganda: Survey experiences from Mpigi and Gulu districts. Journal of Ethnobiology and Ethnomedicine, 10:9.

Panchal, P. and Parvez, N. (2019). Phytochemical analysis of medicinal herb (Ocimum sanctum). International Journal of Nanomaterials Nanotechnology Nanomedicine, 5(2):008-011.

Ponnusamy, K.; Jancy, G. and Nagarajan, R. (2009). Indigenous Technical Knowledge (ITK) in dairy enterprise in coastal Tamil Nadu. Indian Journal of Traditional Knowledge, 8(2):206-211.

Rajannna, N.; Mahender, M.; Thammiraju, D.; Nagalakshmi, D. and Sreenivasarao, D. (2013). Housing and healthcare management practices adopted by sheep farmers in Telangana region of Andhra Pradesh. Veterinary Research, 6(3):64-67.

Rahman, M. M. (2012). Practice of indigenous knowledge system by the farmers in maintaining ecosystem in Bangladesh. Journal of Agricultural Sciences, 57(3):155-168.

Rao, A.W.; Van, D. B.; Rangnekar, D.V.and Ranganathan. K. (1995). Indigenous technical knowledge and livestock. Handbook for straw feeding systems, Kiran Singh and J.B. Schiere (eds.), ICAJR, New Delhi, India.

Reinjtjes, C.; Haverkort, B. and Bayer, A. W. (1992). Farming for future: an introduction to low external input and sustainable agriculture; ILEIA, Leusdan, Netherlands, 52:210-218.

Santosh and Chhetry, G. K. N. (2012). Agrobiodiversity management related ITKs in North-Eastern India. Journal of Biology, Agriculture and Healthcare, 2(6):83-92. 
Salem, M. L.; Alenzi, F.Q. and Attia, W.Y. (2011). Thymoquinone, the active ingredient of Nigella sativa seeds, enhances survival and activity of antigen-specific CD8-positive $\mathrm{T}$ cells in vitro. British Journal Biomedical Science, 68(3):131-7.

Sehgal, A.B. and Sood, S.K., (2013). "Ethnoveterinary practices for herba cure of livestock used by rural populace of Hamirpur, (H.P.), India. IOSR Journal of Agriculture and Veterinary Science (IOSR-JAVS), 3(1):07-14

Sengupta, A. and Bhattacharjee, S. (2009). Cardamom (Elettaria cardamomum) and its active constituent, i,8-cineole. Molecular Targets and Therapeutic uses of Spices, pp:65-85.

Shah, B.N.; Set,A. K. and Desai, R.V. (2010). Phytopharmacological profile of Lagenaria siceraria: A review. Asian Journal of Plant Sciences, 9:152-157.

Shah, P.; Dhande, S.; Joshi, Y. and Kadam, V. (2013). A reiew on Cucumis sativus (cucumber). Research Journal of Pharmacognosy and Phytochemistry, 5(2):49-53.

Shubeena, S.; Hai, A.; Hamdani, S. A. and Akand, A. H. (2018). Indigenous Technical Knowledge (ITKs) used by farmers of central Kashmir to increase production and reproduction in livestock. International Journal of Livestock Research., 8(8):294-302.

Singh, B.D. and Tyagi, S. (2014). Popular ITK practices in Kumaon region of Uttarakhand. Asian Agri-History, 18(1):43-51.

Singh, S.K. and Chauhan J. (2010). Perceived effectiveness of ITK among livestock owners, Indian Research Journal of Extension Education, 10 (1):12-14.
Soni, S.; Anandjiwala, S.; Patel, G. and Rajani, M. (2008). Validation of different methods of preparation of Adhatoda vasica leaf juice by quantification of total alkaloids and vasicine. Indian Journal of Pharmacology Science, 70(1):36-42.

Sri Balaji, N and Chakravarthi, P.V. (2010). Ethnoveterinary practices in India: A review. Veterinary World, 3(12):549-551.

Syed, Q. A.; Rashid, Z; Ahmad, H. M.; Shukat, R.; Ishaq, A.; Muhammad, N. and Hafiz U. U. R. (2020). Nutritional and therapeutic properties of fenugreek (Trigonella foenum-graecum): A review. International Journal of Food Properties, 23(1):1777-1791.

Tewari, D.; Tripathi, Y. C. and Anjum, N. (2014). Agave sislana: A plant with high chemical diversity and medicinal importance. World Journal of Pharmaceutical Research., 3(8):238-249.

Trease, G.E. and Evans, W.C. (2002). Pharmacognosy. 15th Edn., Saunders, New York, pp:258.

Vedam, V. V. A; Xavier, A. S. and David, D. C. (2019). In vitro evaluation of antifungal and anticancer properties of Tagetes Erecta petal extract. Biomedical and Pharmacology Journal, 12(2):815-823.

Walekhwa, M. N.; Ogeto, T. K.; Murithi, K. M. and Malago, Z. L. (2020). Pharmacological effects of Sesbania sesban: A systematic review. International Journal of Research in Medical Sciences, 8(3):11851194.

Xiao, Y.; Yang, Y.; Yong, J. and Lu, C. (2019). Chemical components and biological activities of Areca catechu L.: A mini review. Biomedical Research and Reviews, 3:1-4. 